\title{
Validation of NP Fertilizer Rates on Medium Maturing Maize Varieties at Jimma, South Western Ethiopia
}

\author{
Sisay Gurmu Muhidin Biya EshetuYadete \\ Jimma Agricultural Research Center, P. O. Box 192, Jimma, Ethiopia
}

\begin{abstract}
Maize is the primary staple crop in Ethiopia and plays an important role in the livelihood of the people of Ethiopia. However, its productivity is very low mainly due to low soil fertility and use approved maize varieties. After three years on farm field study of NP Fertilizer Rates on medium maturing maize varieties further evaluation and validation was conducted to determine optimum NP fertilizer rates and best medium maturing maize variety at Jimma Zone, Southwestern Ethiopia during 2019 main cropping season. The experiment had two N/ $\mathrm{P}_{2} \mathrm{O}_{5} ; 92 / 69$ and 115/86 $\mathrm{kg} \mathrm{ha}^{-1}$ and two medium maturing maize varieties. Each treatment was assigned to each plot in Randomized Complete Block Design (RCBD) in factorial arrangement. Data on the yield and yield components were subjected to ANOVA using SAS version 9.3. The highest grain yield $7350 \mathrm{~kg} \mathrm{ha}^{-1}$ and above ground biomass 14.53 ton $\mathrm{ha}^{-1}$ were recorded from BH547 with application of 115/86 kg ha ${ }^{-1} \mathrm{~N} / \mathrm{P}_{2} \mathrm{O}_{5}$ fertilizer rate which was statistically at par with planting BH546 maize variety and application of $92 / 69 \mathrm{~kg} \mathrm{ha}^{-1} \mathrm{~N} / \mathrm{P}_{2} \mathrm{O}_{5}$ fertilizer rate with the highest net benefit 41,855 Ethiopian Birr ha-1 ${ }^{-1}$ Therefore, a medium maturing maize variety BH546 with the application of $92 / 69 \mathrm{~kg} \mathrm{ha}^{-1} \mathrm{~N} / \mathrm{P}_{2} \mathrm{O}_{5}$ fertilizer rates can be taken as optimal and recommended for farmers under rain fed condition in Omonada woreda of Jimma zone and other similar humid agro-ecologies of the southwestern Ethiopia.
\end{abstract}

Keywords: Maize variety, Nitrogen, Phosphorous and fertilizer rate

DOI: $10.7176 / \mathrm{JBAH} / 10-21-04$

Publication date: November $30^{\text {th }} 2020$

\section{Introduction}

Maize is the primary staple crop in Ethiopia and plays an important role in the livelihood of the people of Ethiopia. In Ethiopia, future increases in maize production to meet domestic demand will have to rely on improvements in yield per hectare rather than on the expansion of maize production area. Enhanced maize productivity can be achieved by increased use of modern production techniques such as the adoption of hybrid maize varieties in line with the use of fertilizer application and appropriate crop management practices.

Declining soil fertility and management of plant nutrients aggravate the challenge of agriculture to meet the world increasing demand for food in a sustainable way. Insufficient application of nutrients and poor soil management, along with harsh climatic conditions and other factors, have contributed to the degradation of soils including soil fertility depletion in developing countries, especially in SSA (Goulding et al., 2008). Poor soil fertility is one of the principal factors that limit maize productivity in maize growing areas of Ethiopia (Abebayehu et al., 2011). Degradation of soil physico-chemical properties, soil acidity with high $\mathrm{P}$ sorption and soil nutrient depletion due to low chemical fertilizer use by most small-holder farmers who cannot afford the expensive fertilizers leads to declining in maize production in SSA (Vanlauwe et al., 2010).

Among plant nutrients nitrogen is a vitally important, a major yield determining nutrient and its availability in sufficient quantity throughout the growing season is essential for optimum maize growth (Kogbe and Adediran, 2003). It is a component of protein, nucleic acids and other compounds essential for plant growth process (Onasanya et al., 2009). Whereas phosphorus is the second most important nutrient element (after nitrogen) limiting agricultural production (Kogbe and Adediran, 2003). It is used for growth, utilization of sugar and starch, photosynthesis, metabolic process which leads to higher yield of the crop (Ayub et al., 2002).

Some soil types in Ethiopia contain enough amounts of essential nutrients for the plant's development. But the majority of soils in the country contains low to medium total $\mathrm{N}$ and found inherently low in available P. This could be due to long term cultivation practice that depletes plant nutrients and soil resource degradation as a result of soil erosion and run-off and this becomes a threat to agricultural productivity in Ethiopia. Current observation in maize production field show multi-nutrient deficiencies even in plots where farmer attempted to apply fertilizers at rates they claim optimal for expected yield levels. Thus, NP fertilizers must be applied at rates that can provide better yield advantage and economical that coincides with peak need by the crop.

Therefore, it is an appropriate to know how fertilizer studies on recently released medium maturing maize varieties that have been developed for use in different agro-ecologies of Ethiopia. Hence, the experiment was done with the objective to validate the effect of NP fertilizer rates on medium maturing maize varieties at Jimma Zone; and to identify the economic optimum rate of NP fertilizer rate. 


\section{Materials and Methods}

\subsection{Description of the Study Area}

Field farm experiment was conducted in three sites of Jimma Zone Omonada woreda, Southwestern Ethiopia during main cropping season of 2019. The sites were located on $7^{\circ} 46^{\prime} \mathrm{N}$ and $36^{\circ} 00^{\prime} \mathrm{E}$ and laid at an altitude of 1753 m.a.s.l. with soil type of the area is Upland: Chromic Nitosol and Combisol. The average maximum and minimum temperature are $9^{\circ} \mathrm{C}$ and $28^{\circ} \mathrm{C}$ respectively and reliably receive good rains $1561 \mathrm{~mm}$ per annum cropping season.

\subsection{Soil Physico-chemical Properties}

The soil of the experimental field was characterized by selected physico-chemical properties before the application of the treatments (Table 1). The average soil $\mathrm{pH}$ was 4.97 which was strongly acidic (Batjes, 1995) and ideal for the production of most field crops. The $\mathrm{pH}$ of the soil affects maize growth by suppressing the root development and reducing availability of macronutrients to plants especially phosphorus (Brady and Weil, 2008). The soil total $\mathrm{N}(0.174 \%)$ and SOM (3.53\%) was medium for crop growth and development (Berhanu, 1980). For all locations the Bray II extractable available P was $17.9 \mathrm{mg} \mathrm{kg}^{-1}$ which was above the critical level $\left(8 \mathrm{mg} \mathrm{kg}^{-1}\right)$ for most crops as described by Tekalign and Haque (1991).

Table 1 Selected physico-chemical properties of the soil of the experimental sites before planting at Omonada woreda

\begin{tabular}{llll}
\hline Soil characters & Value & \multicolumn{1}{c}{ Rating } & Reference \\
\hline $\mathrm{pH}(1: 2.5)$ & 4.97 & Strongly acidic & Batjes(1995) \\
$\mathrm{Av} \mathrm{P}\left(\mathrm{mg} \mathrm{kg}^{-1}\right)$ & 17.9 & High & Olsen et al., 1954 \\
$\mathrm{TN}(\%)$ & 0.174 & Medium & Berhanu (1980) \\
$\mathrm{OC}(\%)$ & 2.05 & High & Tekalign(1991) \\
SOM $(\%)$ & 3.53 & Medium & Berhanu (1980) \\
C:N ratio & 11.78 & Low & Brady and Weil, 2002 \\
\hline
\end{tabular}

Where $\mathrm{pH}=$ hydrogen power, $\mathrm{TN}=$ Total Nitrogen, $\mathrm{Av} \mathrm{P}=$ Available Phosphorous, $\mathrm{OC}=$ Organic Carbon, $\mathrm{SOM}=$ Soil Organic Carbon. Values are the means of duplicated samples.

Source: Jimma Agricultural Research Center soil and plant laboratory

\subsection{Experimental treatment and procedures}

The experimental field was ploughed and prepared following the conventional tillage practice before planting at all locations. The land was leveled using manual power before the field layout was made. The maize was planted during 18 up to 22 May at different locations. Two maize seeds were planted per hill and then thinned to one plant per hill after good establishment of seedlings so as to maintain a single healthy plant per hill. This experiment had four treatments with farmers replications which were two $\mathrm{NP}_{2} \mathrm{O}_{5} ; 92 / 69$ and 115/86 $\mathrm{kg} \mathrm{ha}^{-1}$ and two medium maturing maize varieties; BH546 and BH547 which were storage pest resistant and are well adapted to low-mid altitude (1000-1800 m.a.s.1) areas. They were white-colored and used for experiment to maximize yield potential of smallholder farmers. Totally 4 treatments were laid out in a factorial randomized complete block design. The plot size $45 \mathrm{~m}^{2}(4.5 \mathrm{~m} \times 10 \mathrm{~m})$ was used for each treatment.

Nitrogen and phosphorus fertilizers were applied, respectively per stand or hill base. Nitrogen fertilizer rates were applied during planting and knee height stage to increase the nitrogen use efficiency. All other agronomic practices were applied uniformly to all experimental plots in the study area.

The experimental field was prepared following the conventional tillage practice and furrow opened by using oxen. Two maize seeds were planted per hill and thinned after establishment to maintain a single healthy plant per hill. All other agronomic practices like three times hand weeding were applied uniformly to both experimental plots as per their respective recommendations for maize in the study area.

\subsection{Data collected}

2.4.1 Plant height (cm): it was measured at ground level to terminal stem using measuring stick at the point where the tassel starts branching from six randomly selected plants.

2.4.2 Number of ear per plant: it was obtained by counting total number of ears in each plot and divided to total number of plant stand harvested.

2.4.3 Stem diameter (girth): it was measured at $50 \mathrm{~cm}$ from the ground level on six randomly selected plants using caliper.

2.4.4 Grain yield $\left(\mathrm{kg} \mathrm{ha}^{-1}\right)$ : grain yield per plot was recorded using electronic balance and then adjusted to $12.5 \%$ moisture and converted to hectare basis.

2.4.5 Above ground biomass $\left(\mathrm{kg} \mathrm{ha}^{-1}\right)$ : all above ground biomass was harvested from net plot and weighted, ears were removed and weighted separately, six plants were selected, chopped and oven dried till get uniform weight. 2.4.6 Lodging percent: it was obtained by counting the total number of stalk and root lodging in each plot and 
divided to the total number of plant stand at harvesting.

2.4.7 Harvest index: was calculated as the ratio of grain yield to above ground biomass yield on dry weight basis (Donald, 1962). HI (\%) $=\frac{\text { Economic yield }(\mathrm{kg} / \mathrm{ha})}{\text { Total biological yield }(\mathrm{kg} / \mathrm{ha})} \times 100$

\subsection{Data analysis}

Analysis of variance (ANOVA) for all collected data was computed using SAS version 9.3 statistical software. Whenever the ANOVA results showed the significant differences between sources of variation, the means were compared using least significant difference. The homogeneity test was done as suggested by Gomez and Gomez, (1984).

\subsection{Partial budget analysis}

Partial budget analysis was performed to investigate the economic feasibility of the treatments and assess the costs and benefits associated with different treatments of chemical fertilizers and the seed rates. The partial budget technique as described by CIMMYT (1988) was applied. The partial budget analysis was done using the prevailing market prices for inputs at planting and for outputs at the time the crop was harvested. All costs and benefits were calculated on hectare basis in Ethiopian Birr (ETB). The inputs and/or concepts used in the partial budget analysis were the mean grain yield of each treatment, the gross field benefit (GFB) ha ${ }^{-1}$ (the product of field price and the mean yield for each treatment), the field price of chemical fertilizers and urea $\mathrm{kg}^{-1}$ (the nutrient cost plus the cost of transportation from the point of sale to the farm), cost of labor spent on seed purchase and planting, the total costs that varied (TVC) which included the sum of field costs of fertilizers and their application, and seed purchase and planting.

\section{Results and Discussions}

After three years experiment of NP fertilizer effect on medium maturing maize varieties, further evaluation and validation was done at three farmers' sites during 2019 main cropping season at Jimma zone Omonada woreda.

The statistical analysis results indicates the interaction and main effect of NP fertilizer rates and maize varieties didn't show significant $(\mathrm{P}>0.05)$ difference on plant height, number of ear per plant, stem diameter (girth), lodging percent and HI. However grain yield and above ground biomass were significantly $(\mathrm{P} \leq 0.01)$ affected by interaction effect of NP fertilizer rates and maize varieties. But, both grain yield and above ground biomass were not significantly $(\mathrm{P}>0.05)$ influenced by main effect of NP fertilizer rates and maize varieties (Table 2$)$.

Table 2 Mean square values of NP fertilizer rates on growth, yield components and yield of medium maturing maize varieties

\begin{tabular}{lllll}
\hline \multirow{2}{*}{ Parameter } & \multicolumn{3}{l}{ Mean square for source of variation } & \\
\cline { 2 - 5 } & NP $(1)$ & Maize Varieties (1) & $\begin{array}{l}\text { NP } \begin{array}{c}\text { x } \\
\text { varieties (1) }\end{array} \\
\text { Maize }\end{array}$ & $\begin{array}{l}\text { Error } \\
(6)\end{array}$ \\
\hline Plant height $(\mathrm{cm})$ & $0.08^{\mathrm{ns}}$ & $90.75^{\mathrm{ns}}$ & $2.08^{\mathrm{ns}}$ & 79.14 \\
Ears per plant & $0.003^{\mathrm{ns}}$ & $0.003^{\mathrm{ns}}$ & $0.000001^{\mathrm{ns}}$ & 0.016 \\
Girth $(\mathrm{cm})$ & $0.001^{\mathrm{ns}}$ & $0.029^{\mathrm{ns}}$ & $0.001^{\mathrm{ns}}$ & 0.024 \\
Lodging (\%) & $0.18^{\mathrm{ns}}$ & $36.999^{\mathrm{ns}}$ & $26.19^{\mathrm{ns}}$ & 10.88 \\
Grain yield $\left(\mathrm{kg} \mathrm{ha}^{-1}\right)$ & $278678.6^{\mathrm{ns}}$ & $91577.7^{\mathrm{ns}}$ & $1451091.2^{*}$ & 169579.4 \\
AGB $\left(\mathrm{t} \mathrm{ha}^{-1}\right)$ & $0.273^{\mathrm{ns}}$ & $0.01^{\mathrm{ns}}$ & $1.928^{*}$ & 0.302 \\
Harvest index & $0.0001^{\mathrm{ns}}$ & $0.003^{\mathrm{ns}}$ & $0.00003^{\mathrm{ns}}$ & 0.00039 \\
\hline
\end{tabular}

*Numbers in parenthesis $=$ Degrees of freedom; *= Significant $(\mathrm{P} \leq 0.05) ; \mathrm{NS}=$ non significant; $\mathrm{AGB}=\mathrm{Above}$ ground biomass; ha = Hectare

Grain yield

Numerically the highest grain yield $7350 \mathrm{~kg} \mathrm{ha}^{-1}$ was recorded from BH547 maize variety with application of $115 / 86 \mathrm{~kg} \mathrm{ha}^{-1} \mathrm{NP}_{2} \mathrm{O}_{5}$ fertilizer rate which was statistically at par with application of $92 / 69 \mathrm{~kg} \mathrm{ha}^{-1} \mathrm{NP}_{2} \mathrm{O}_{5}$ fertilizer and BH546 maize variety. While, the lowest grain yield $6350 \mathrm{~kg} \mathrm{ha}^{-1}$ was recorded from BH547 maize variety with application of $92 / 69 \mathrm{~kg} \mathrm{ha}^{-1} \mathrm{NP}_{2} \mathrm{O}_{5}$ fertilizer rate (Table 3). The data also showed that by application of $92 / 69 \mathrm{~kg}$ $\mathrm{ha}^{-1} \mathrm{NP}_{2} \mathrm{O}_{5}$ fertilizer and planting $\mathrm{BH} 546$ maize variety there was $13.7 \%$ grain yield increase over planting BH547 maize variety with application of $92 / 69 \mathrm{~kg} \mathrm{ha}^{-1} \mathrm{NP}_{2} \mathrm{O}_{5}$ fertilizer rate. Such reduction of grain yield might be due to nutritional imbalance and deficiency of certain important plant growth elements at various important growth stages and also due to reduced leaf area development, stem diameter, number of ear plant, high lodging percent and also plant height of maize varieties resulting in lesser radiation interception and, consequently, low efficiency in the conversion of solar radiation. The higher doses of chemical fertilizers increased grain yield as nutrients are the main driving force to produce high yield of maize (Nivong et al., 2007). These results were in line with findings of Ghimire et al. (2016) who reported that grain yield was significantly affected by crop varieties sown. Also Udoh (2005) reported that some hybrid maize varieties have a yield advantage over other maize varieties because they 
possess high grain yield uniformity in flowering and ear placement.

Table 3 Interaction and main effects of NP fertilizer and medium maturing maize varieties on growth, yield and yield components at Omonada woreda during 2019 cropping season

\begin{tabular}{llllllll}
\hline $\begin{array}{l}\mathrm{N} / \mathrm{P}_{2} \mathrm{O}_{5} \\
\left(\mathrm{Kg} \mathrm{ha}^{-1}\right)\end{array}$ & $\begin{array}{l}\text { Maize } \\
\text { varieties }\end{array}$ & $\begin{array}{l}\text { Plant } \\
\text { height } \\
(\mathrm{cm})\end{array}$ & $\begin{array}{l}\text { Lodging } \\
\text { harvesting }\end{array}$ & $\begin{array}{l}\text { atEars } \\
\text { plant }\end{array}$ & $\begin{array}{l}\text { perStem } \\
\text { diameter(cm) }\end{array}$ & $\begin{array}{l}\text { Grain yield } \\
\left(\text { ton ha }^{-1}\right)\end{array}$ & $\begin{array}{l}\left.\text { AGB }^{1}\right) \\
\text { (ton ha }\end{array}$ \\
\hline \multirow{2}{*}{$92 / 69$} & $\mathrm{BH} 546$ & 256.0 & 72.30 & 1.0 & 2.48 & $7.22 \mathrm{a}$ & $14.29 \mathrm{a}$ \\
& $\mathrm{BH} 547$ & 249.7 & 78.8 & 0.93 & 2.40 & $6.35 \mathrm{~b}$ & $13.43 \mathrm{~b}$ \\
\hline $115 / 86$ & $\mathrm{BH} 546$ & 255.0 & 75.5 & 0.93 & 2.48 & $6.83 \mathrm{ab}$ & $13.79 \mathrm{ab}$ \\
& $\mathrm{BH} 547$ & 250.3 & 76.06 & 0.90 & 2.36 & $7.35 \mathrm{a}$ & $14.53 \mathrm{a}$ \\
\hline LSD (0.05) & & 26.03 & 37.63 & 0.266 & 0.31 & 0.58 & 0.776 \\
$\mathrm{CV}(\%)$ & & 3.52 & 4.36 & 13.7 & 6.33 & 8.9 & 6.03 \\
F-test & & $\mathrm{NS}$ & $\mathrm{NS}$ & $\mathrm{NS}$ & $\mathrm{NS}$ & $*$ & $*$ \\
\hline
\end{tabular}

$\mathrm{LSD}=$ Least significant difference; $\mathrm{CV}=$ Coefficient of variation; NS=Non significant; $\mathrm{AGB}=\mathrm{Above}$ ground biomass; Values followed by the same letter within a column are not significantly different at $\mathrm{P}<0.05$.

\section{Above Ground Biomass}

Numerically, the highest above ground biomass $14.29 \mathrm{t} \mathrm{ha}^{-1}$ was recorded from BH547 maize variety and application of $115 / 86 \mathrm{~kg} \mathrm{ha}^{-1} \mathrm{NP}_{2} \mathrm{O}_{5}$ fertilizer rate which was statically at par with application of $92 / 69 \mathrm{~kg} \mathrm{ha}^{-1}$ $\mathrm{NP}_{2} \mathrm{O}_{5}$ fertilizer rate on BH546 maize variety. On the contrary, the lowest $13.43 \mathrm{t} \mathrm{ha}^{-1}$ was obtained from the BH547 maize variety and application of $92 / 69 \mathrm{~kg} \mathrm{ha}^{-1} \mathrm{NP}_{2} \mathrm{O}_{5}$ fertilizer rate (Table 3). Above ground biomass yield advantage of $6.4 \%$ was obtained due to planting BH546 maize variety and application of 92/69 $\mathrm{kg} \mathrm{ha}^{-1} \mathrm{NP}_{2} \mathrm{O}_{5}$ fertilizer rate when compared with the same fertilizer rate and use of BH547 maize variety.

The result showed that the above ground biomass was increased due to higher number of ear per plant, plant height and grain yield. Adequate supply of nutrients to the crop helps in the synthesis of carbohydrates, which are required for the formation of protoplasm, thus resulting in higher cell division and cell elongation. Thus an increase in biomass yield might have been on account of overall improvement in the vegetative growth of the plant due to the application of NP fertilizer with the variety we use. These results were in agreement with Tariku et al., (2018) reported that application of higher chemical fertilizer increased the dry matter of plants.

\section{Harvest index}

Significantly higher harvest index of 0.50 was obtained from BH546 maize variety, while the lowest harvest index 0.47 was recorded from BH547 maize variety (Figure 1). Harvest index obtained were in the acceptable range of 0.4 - 0.6 for maize (Hay, 1995).

Adequate supply of chemical fertilizer is essential for optimizing partitioning of dry matter between grain and other parts of the maize plant. Optimum utilization of solar radiation, higher assimilates production and its conversion to starch results in higher biomass, grain yield leading to higher harvest index.
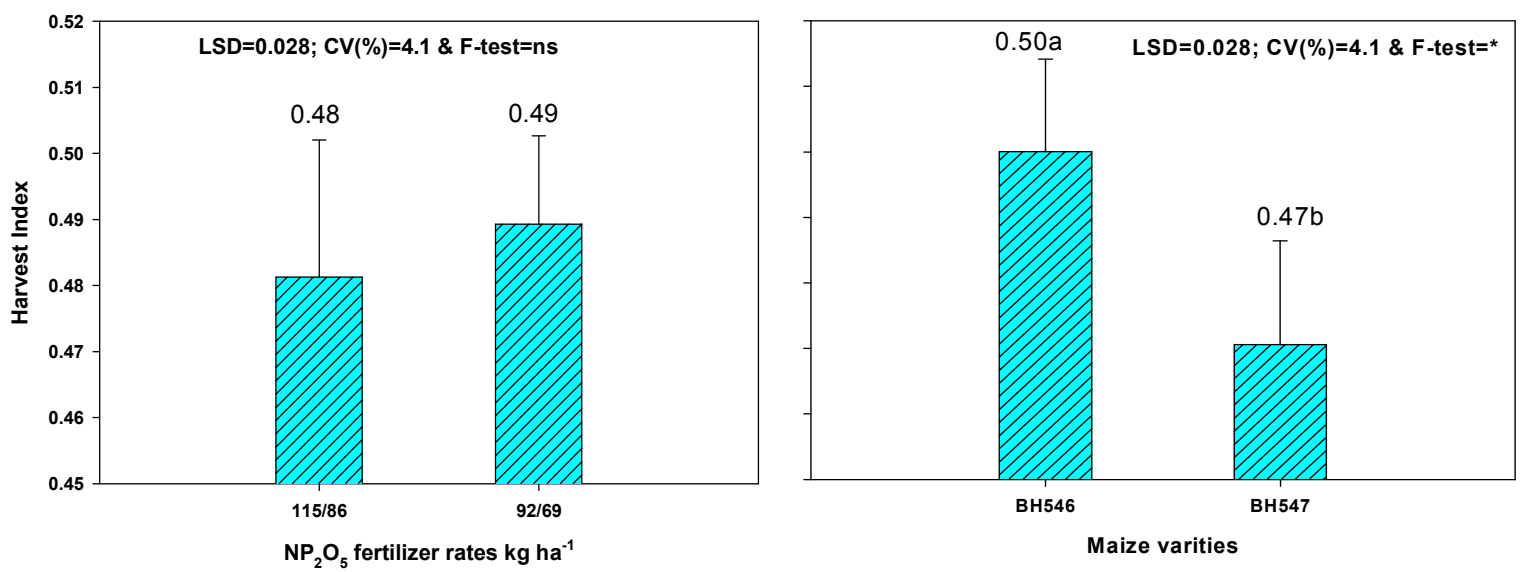

*LSD = Least Significant Difference; CV = Coefficient of Variation; Values followed by the same letter(s) within main treatment rates are not significantly different at 0.05 probability level.

Figure 1 Effect of NP fertilizer rate and medium maturing maize varieties on harvest index

Partial Budget Analysis

Analysis of variance (Table 2) showed that maize verities and NP fertilizer rates had a significant $(\mathrm{P}<0.05)$ interaction effect on the grain yield.

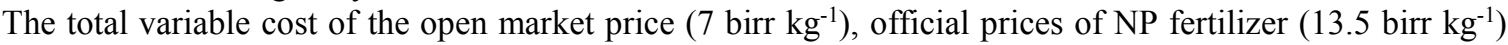


and urea $\left(10\right.$ birr $\left.\mathrm{kg}^{-1}\right)$ were used for analysis. The cost of application and transport for fertilizer was taken to be 15 birr $100 \mathrm{~kg}^{-1}$. Grain yield was adjusted by $10 \%$ for management difference to reflect the difference between the experimental yield and the yield that farmers could expect from the same treatment (Getachew and Taye, 2005, CIMMYT, 1988).

Table 4. Partial budget analysis of NP fertilizer rates on grain yield of medium maturing maize varieties at Omonada woreda during 2019 cropping season

\begin{tabular}{lllllll}
\hline $\begin{array}{l}\mathrm{N} / \mathrm{P}_{2} \mathrm{O}_{5} \\
\left(\mathrm{Kg} \mathrm{ha}^{-1}\right)\end{array}$ & Maize varieties & $\begin{array}{l}\mathrm{GY} \\
\left(\mathrm{kg} \mathrm{ha}^{-1}\right)\end{array}$ & $\begin{array}{l}\text { Adj.GY } \\
\left(\mathrm{kg} \mathrm{ha}^{-1}\right)\end{array}$ & $\begin{array}{l}\text { GFB } \\
\left(\mathrm{ETB} \mathrm{ha}^{-1}\right)\end{array}$ & $\begin{array}{l}\text { TVC } \\
\left(\mathrm{ETB} \mathrm{ha}^{-1}\right)\end{array}$ & $\begin{array}{l}\text { NB } \\
\left(\mathrm{ETB} \mathrm{ha}^{-1}\right)\end{array}$ \\
\hline \multirow{2}{*}{$92 / 69$} & BH546 & 7220 & 6498.0 & 45486 & 3631 & 41855 \\
& BH547 & 6350 & 5715.0 & 40005 & 3631 & 36374 \\
\hline \multirow{2}{*}{$115 / 86$} & BH546 & 6830 & 6147.0 & 43029 & 4530 & 38499 \\
& BH547 & 7350 & 6615.0 & 46305 & 4530 & 41775 \\
\hline
\end{tabular}

${ }^{*} \mathrm{GY}=$ Grain yield; GFB $=$ Gross field benefit; $\mathrm{TVC}=$ Total Variable cost; $\mathrm{NB}=$ Net benefit; $\mathrm{ETB}=$ Ethiopian Birr; Price of chemical fertilizer $=13.5$ birr kg-1 ; Price of Urea $=10$ birr $\mathrm{kg}^{-1}$; Wage rate $=40$ Birr man-day ${ }^{-1}$; Retail price of grain $=7$ birr kg-1.

The data presented in Table 4 indicates that the highest net benefit $\left(41,855 \mathrm{ETB} \mathrm{ha}^{-1}\right)$ was obtained from fertilizer application of $92 / 69 \mathrm{~kg} \mathrm{ha}^{-1} \mathrm{~N} / \mathrm{P}_{2} \mathrm{O}_{5}$ and $\mathrm{BH} 546$ medium maturing maize variety. Whereas, the lowest net benefit ( $36374 \mathrm{ETB} \mathrm{ha}^{-1}$ ) was obtained from BH547 maize variety and application of $92 / 69 \mathrm{~kg} \mathrm{ha}^{-1} \mathrm{~N} / \mathrm{P}_{2} \mathrm{O}_{5}$ fertilizer. Due to application of $92 / 69 \mathrm{~kg} \mathrm{ha}^{-1} \mathrm{~N} / \mathrm{P}_{2} \mathrm{O}_{5}$ fertilizer and planting BH546 maize variety, there was net benefit increase by $15.1 \%\left(5484 \mathrm{ETB} \mathrm{ha}^{-1}\right)$ when compared with planting BH547 maize variety with the application of the same fertilizer rate.

The farmers' perceptions were collected at the green ear stage and at harvest period. Six maize stand evaluation criteria were set by farmers to select best medium maturing maize variety and optimal fertilizer application. Accordingly, maize growth rate, probability of lodging, number of ears/plant and yield potential were found the most important for the maize stand evaluation criteria. Further, based on maize stand evaluation criteria's that was set by farmers (Table 5) $29 \%$ of them chosen BH546 maize variety with application of $92 / 69 \mathrm{Kg} \mathrm{ha}^{-1}$ $\mathrm{N} / \mathrm{P}_{2} \mathrm{O}_{5}$ fertilizer rate.

Table 5 Farmers perception on optimal NP fertilizer application and medium maturing maize varieties at Jimma zone during 2019 cropping

\begin{tabular}{|c|c|c|c|c|}
\hline \multirow{4}{*}{$\begin{array}{l}\text { Farmers Evaluation } \\
\text { Criteria }\end{array}$} & \multicolumn{4}{|c|}{ NP fertilizer rates } \\
\hline & \multicolumn{2}{|c|}{$92 / 69 \mathrm{NP}_{2} \mathrm{O}_{5}\left(\mathrm{Kg} \mathrm{ha}^{-1}\right)$} & \multicolumn{2}{|c|}{$115 / 86 \mathrm{NP}_{2} \mathrm{O}_{5}\left(\mathrm{Kg} \mathrm{ha}^{-1}\right)$} \\
\hline & \multicolumn{4}{|c|}{ Medium maturing maize varieties } \\
\hline & BH546 & BH547 & BH546 & BH547 \\
\hline Weeding Frequency & Medium & Medium & Medium & Medium \\
\hline Growth rate & Medium & Medium & High & High \\
\hline Probability of lodging & Low & Medium & Low & Medium \\
\hline Number of ears/plant & 1 & 1 & 1 & 1 \\
\hline Cob size & Bigger & Medium & Bigger & Medium \\
\hline Number of ear rotting & low & low & low & low \\
\hline Yield potential & Higher & Medium & Higher & Medium \\
\hline choice in Percentage & $29 \%$ & $23 \%$ & $22 \%$ & $26 \%$ \\
\hline
\end{tabular}

\section{Summary and Conclusions}

Enhanced maize productivity can be achieved by increased use of modern production techniques such as the adoption of hybrid maize varieties in line with the use of optimum fertilizer application and appropriate crop management practices. In view of this, the study was conducted to validate the response of medium maturing maize varieties to different rates of NP fertilizer at Jimma zone Omonada Woreda, southwestern Ethiopia.

Accordingly, the research efforts were made on farmer's fields of Jimma zone Omonada woredas in vicinity of the Jimma Agricultural research center for three cropping seasons (2016-2018) and validation of the experiment was performed in 2019 main cropping season. From all, the grain yield and above ground biomass was significant 
$(\mathrm{P}<0.05)$ for interaction effect of NP fertilizer rate and maize varieties. The highest grain yield $7350 \mathrm{~kg} \mathrm{ha}^{-1}$ and above ground biomass $14.53 \mathrm{t} \mathrm{ha}^{-1}$ was recorded from BH547 maize variety and 115/86 kg ha-1 $\mathrm{N} / \mathrm{P}_{2} \mathrm{O}_{5}$ fertilizer rate which was statistically at par with application of 92/69 $\mathrm{kg} \mathrm{ha}^{-1} \mathrm{~N} / \mathrm{P}_{2} \mathrm{O}_{5}$ fertilizer application on BH546 maize variety for both grain yield and above ground biomass. The partial budget analysis based on the field prices of inputs and maize grain yield showed that, the use of BH546 maize variety with application of $92 / 69 \mathrm{~kg} \mathrm{ha}^{-1} \mathrm{~N} / \mathrm{P}_{2} \mathrm{O}_{5}$ fertilizer gave the highest net benefit $\left(41,855 \mathrm{ETB} \mathrm{ha}^{-1}\right)$. Therefore, from current on-farm input availability and economic feasibility, a medium maturing maize variety BH546 with the application of 92/69 kg ha- ${ }^{-1} / \mathrm{P}_{2} \mathrm{O}_{5}$ fertilizer rates can be taken as optimal and recommended for farmers under rain fed condition in Omonada woreda of Jimma zone and other similar humid agro-ecologies of the southwestern Ethiopia.

\section{REFERENCES}

Abebayehu, A., Elias, E. and Diels, J., 2011. Comparative analysis of soil nutrient balance at farm level: a case study in Jimma Zone, Ethiopia. International Journal of Soil Science, 6(4): 259-266.

Ayub, M., Nadeem, M.A., Sharar, M.S. and Mahmood, N., 2002. Response of maize fodder to different levels of nitrogen and phosphorus. Asian Journal of Plant Science, 1(4): 352-354.

Batjes, N.H., 1995. Aglobal data set of soil pH properties. Technical Paper 27, International Soil Reference and Information Centre (ISRIC), Wageningen.

Brady, N. and Weil, R.R., 2002. The nature and properties of soils. 13 edn. Prentince Hall. New Jersey, USA. 598 p.

Brady, N. and Weil, R.R., 2008. Nature and Properties of Soils (14th edn.). Prentice Hall, Upper Saddle River. 992p.

Berhanu, D., 1980. A survey of studies conducted about soil resources appraisal and evaluation for rural development in Ethiopia, Addis Ababa.70p

Donald, C. M., 1962. In search of yield. Journal of Australian Institute of Agricultural Science, 28(1): 171-178.

CIMMYT, 1988. From Agronomic Data to Farmer Recommendations: An Economics Training Manual. Completely revised edition. Mexico, D.F.79p.

Getachew, A., and Taye, B., 2005. On-farm integrated soil fertility management in wheat on nitisols of central Ethiopian highlands. Ethiopian Journal of Natural Resources, 7: 141-155.

Ghimire, S., Sherchan, D.P., Andersen, P., Pokhrel, C., Ghimire, S. and Khanal, D., 2016. Effect of Variety and Practice of Cultivation on Yield of Spring Maize in Terai of Nepal.

Gomez, K A. and A. A. Gomez. 1984. Statistical Procedures for Agricultural Research. 2nd ed. John Wiley and Sons. New York.

Goulding K., Jarvis S., Whitmore A., 2008. Optimizing nutrient management for farm systems. Philosophical Transactions of the Royal Society of London: Biological Sciences, 363(1): 667-680.

Hay, R.K.M., 1995. Harvest index: a review of its use in plant breeding and crop physiology. Annals of applied biology, 126(1), pp.197-216.

Kogbe, J.O.S. and Adediran, J.A., 2003. Influence of nitrogen, phosphorus and potassium application on the yield of maize in the savanna zone of Nigeria. African Journal of Biotechnology, 2(10): 345-349.

Nivong, S., Tasnee, A. and Russell, Y., 2007. Nitrogen fertilizer response of maize on some important soils from DSSAT software prediction. Natural Science, 41(1): 21-27.

Olsen, S.R., Cole, C., Watanable, F.S. and Dean, L.A., 1954. Estimation with sodium phosphorus in soil by extraction with sodium bicarbonate, USDA Circular, 939: 1-19.

Onasanya, R.O., Aiyelari, O.P., Onasanya, A., Oikeh, S., Nwilene, F.E. and Oyelakin, O.O., 2009. Growth and yield response of maize to different rates of nitrogen and phosphorus fertilizers in southern Nigeria. World Journal of Agricultural Sciences, 5(4): 400-407.

Shah, S.T.H., Zamir, M.S.I., Waseem, M., Ali, A., Tahir, M. and Khalid, W.B., 2009. Growth and yield response of maize to organic and inorganic sources of nitrogen. Pakistan Journal of life and social science, 7(2):108111.

Tariku Beyene, ToleraAbera and ErmiyiasHabte, 2018. Effect of Integrated Nutrient Management on Growth and Yield of Food Barley (Hordeumulgare) Variety in Toke Kutaye District, West Showa Zone, Ethiopia

Tekalign, M. and Haque, I., 1991. Phosphorus status of some Ethiopian soils, II. Forms and distribution of inorganic phosphates and their relation to available phosphorus. Tropical Agriculture, 68(1): 2-8.

TekalignTadese. 1991. Soil, Plant, Water, Fertilizer, Animal Manure and Compost Analysis. Working Document No. 13.International Livestock Research Center for Africa (ILCA), Addis Ababa, Ethiopia.

Udoh, J., 2005. Crop Production Techniques for the Tropics Concept Publications Limited, Munshin, Lagos Nigeria, 101-106.

Vanlauwe, B., Bationo, A., Chianu, J., Giller, K.E., Merckx, R., Mokwunye, U., Ohiokpehai, O., Pypers, P., Tabo, R., Shepherd, K.D. and Smaling, E.M.A., 2010. Integrated soil fertility management: operational definition and consequences for implementation and dissemination. Outlook on agriculture, 39(1): 17-24. 